\title{
The pathobiological impact of cigarette smoke on pancreatic cancer development (Review)
}

\author{
UWE A. WITTEL ${ }^{1}$, NAVNEET MOMI ${ }^{3}$, GABRIEL SEIFERT $^{1}$, THORSTEN WIECH $^{2}$, \\ ULRICH T. HOPT ${ }^{1}$ and SURINDER K. BATRA ${ }^{3}$
}

\footnotetext{
${ }^{1}$ Department of General- and Visceral Surgery, ${ }^{2}$ Institute of Pathology, Universitätsklinik Freiburg, Freiburg, Germany;

${ }^{3}$ Department of Biochemistry and Molecular Biology, University of Nebraska Medical Center, Omaha, NE, USA
}

Received November 29, 2011; Accepted January 25, 2012

DOI: $10.3892 /$ ijo.2012.1414

\begin{abstract}
Despite extensive efforts, pancreatic cancer remains incurable. Most risk factors, such as genetic disposition, metabolic diseases or chronic pancreatitis cannot be influenced. By contrast, cigarette smoking, an important risk factor for pancreatic cancer, can be controlled. Despite the epidemiological evidence of the detrimental effects of cigarette smoking with regard to pancreatic cancer development and its unique property of being influenceable, our understanding of cigarette smokeinduced pancreatic carcinogenesis is limited. Current data on cigarette smoke-induced pancreatic carcinogenesis indicate multifactorial events that are triggered by nicotine, which is the major pharmacologically active constituent of tobacco smoke. In addition to nicotine, a vast number of carcinogens have the potential to reach the pancreatic gland, where they are metabolized, in some instances to even more toxic compounds. These metabolic events are not restricted to pancreatic ductal cells. Several studies show that acinar cells are also greatly affected. Furthermore, pancreatic cancer progenitor cells do not only derive from the ductal epithelial lineage, but also from acinar cells. This sheds new light on cigarette smoke-induced acinar cell damage. On this background, our objective is to outline a multifactorial model of tobacco smoke-induced pancreatic carcinogenesis.
\end{abstract}

\section{Contents}

1. Introduction

2. Morphological alterations

3. Enzyme regulation

4. Nicotine and pancreatic regulation

5. Cigarette smoke-related carcinogens and the pancreatic gland

Correspondence to: Dr Uwe A. Wittel, Department of General- and Visceral Surgery, Universitätsklinik Freiburg, Hugstetter Strasse 55, D-79106 Freiburg, Germany

E-mail: uwe.wittel@uniklinik-freiburg.de

Key words: pancreatic cancer, nicotine, nnk, cigarette smoke, carcinogenesis, carcinogens, chronic pancreatitis
6. Acinar cell damage and pancreatic ductal adenocarcinoma

7. Conclusions and perspectives

\section{Introduction}

Pancreatic cancer is the fourth leading cause of death in the United States and the sixth leading cause in Europe affecting between 7 and 9 per 100,000 in men and between 4.5 and 6 per 100,000 in women (1). The cumulative mortality or lifetime risk of dying from pancreatic cancer is approximately $1.3 \%(2,3)$. However, the worldwide mortality/incidence ratio of pancreatic cancer is $98 \%$ indicating that almost all patients diagnosed with pancreatic cancer die of this disease (1). Pancreatic cancer is a rapidly progressive, therapy-resistant disease with a 1-yearsurvival rate of $25 \%$ and a 5-year-survival rate of less than $5 \%$ (4). Thus, primary prevention plays a pivotal role in disease management. However, only few risk factors are clearly established $(2,5)$.

Late-onset diabetes correlates with a relative risk for pancreatic cancer of 2.1 for patients with diabetes persisting at least for 1 year $(6,7)$. For this estimation patients with shortly diagnosed diabetes must be excluded because $40 \%$ of pancreatic cancer patients are diabetic, and there is an increased hazard ratio for developing pancreatic cancer in patients with newly diagnosed diabetes (8-11). The high coincidence of diabetes and pancreatic cancer may provide for new screening strategies. In fact, diagnosing an altered glucagon/insulin ratio may be the first step in identifying pancreatic cancer patients $(12,13)$. In any case, late-onset and early-onset diabetes persisting for more than 5 years prior to cancer diagnosis are risk factors for developing pancreatic cancer (14-17).

Similar to diabetes, obesity has been reported to increase the risk of developing pancreatic cancer (18). Most case-control studies found an increased risk in men and women exceeding a body mass index of 30 (19-21). However, in some cohorts obesity showed this correlation only in men (22), while in other cohorts there was no significant association in either group (23). Therefore, a disturbance in glucose and/or lipid metabolism might be responsible for the association between obesity and pancreatic cancer. This is corroborated by the observation that patients treated with statins to lower cholesterol levels or with metformin to lower pathological glucose levels show a significantly decreased risk for developing pancreatic cancer (24). 
However, in the case of metformin, the reduction of pancreatic cancer risk does not seem to be related to the normalization of blood glucose levels because this reduction was absent in patients treated with insulin or insulin secretagogues (25).

A clearly identified, strong risk-factor for pancreatic cancer is chronic pancreatitis (26-30). The cumulative risk of chronic hereditary pancreatitis patients to develop pancreatic cancer by age 70 has been assessed at almost $40 \%$. Furthermore, in a multinational study including 2,016 patients, the standardized incidence ratio was roughly 16.5 (28). These data point at a role of chronic inflammation in the initiation and progression of pancreatic cancer (31). However, chronic pancreatitis accounts for only 3-4 \% of the pancreatic cancer cases observed (32).

Between 5 and $10 \%$ of pancreatic cancer cases can be accounted to hereditary factors. The risk depends on the number of affected first degree relatives with a hazard ratio of 32.0 when 3 family members are affected and 6.4 with 2 affected family members (33). Between 6 and 19\% of familial pancreatic cancer families have mutations in the BRCA2 gene (34-36), but other germline mutations such as CDKN2A, PRSS1, STKI1, or MMR genes have also been found (37). No single gene defect has been identified to date except for one family, where a mutation in the palladin gene that is only found in affected family members causes a proline to serine amino acid change (38). These results may be the first steps in identifying gene mutations responsible for familial pancreatic cancer (39).

Remarkably, the most frequent risk factor associated with pancreatic cancer development is cigarette smoking (40-43). Cigarette smoke is graded as a class 1 carcinogen by the World Health Organization (44). It is related to $25 \%$ of pancreatic cancer cases, and the risk increases with duration and amount smoked (32). Quitting smoking reduces the excessive risk for pancreatic cancer within 5-10 years (21) with an initial reduction of pancreatic cancer risk of $50 \%$ within the first 2 years (42). Smoking also elevates the risk of patients with familial predisposition to pancreatic cancer, and in patients with hereditary pancreatitis, the onset of pancreatic cancer occurs 10-20 years earlier in smokers than in non-smokers $(45,46)$. Furthermore, cigarette smoking promotes the development of chronic pancreatitis in a dose-dependent manner $(47,48)$, and during chronic pancreatitis smoking further increases disease severity and induces pancreatic calcifications $(49,50)$. Therefore, cigarette smoking is the only amenable risk factor in pancreatic carcinogenesis, and quitting smoking both prevents the development of pancreatic cancer as well as chronic pancreatitis (51).

For several reasons, the experimental work aiming at understanding the mechanisms behind cigarette smoke-mediated pancreatic damage lags behind. Cigarette smoke consists of a mixture of side stream smoke and mainstream smoke containing a blend of chemicals out of which 4,000 have been identified to date. Of the so far identified substances, more than 50 compounds act, or are likely to act as carcinogens (52). Due to this complexity, most studies investigate either the action of nicotine or tobacco-derived carcinogens. Thus causal relationships between individual compounds at high doses and pancreatic carcinogenesis, but not cigarette smoke inhalation have been established. However, most chemicals contained in cigarette smoke are likely to interact with each other or synergize in their detrimental action. Unfortunately, only very few studies reflect this pathophysiological situation. In this review, we discuss recent experimental advances in the evolving field of cigarette smoke-induced pancreatic carcinogenesis. Furthermore, we link the evidence obtained in in vivo and in vitro experiments to observations in humans and discuss possible pathomechanisms involved in cigarette smoke-mediated pancreatic carcinogenesis.

\section{Morphological alterations}

Smoking leads to distinct histomorphological alterations of the pancreas. In autopsy specimens, several investigators have reported alterations described as focal acinar cell hyperplasia or dysplasia (53). These hyperplastic acinar nodules as depicted in Fig. 1A are well demarcated from the surrounding normal acinar cells, measure 300-1,000 $\mu \mathrm{m}$, and are randomly distributed throughout the pancreas. Most of the lesions show only mild nuclear atypia and are therefore referred to as hyperplasia. However, severe dysplastic changes can be observed as well, but only in specimens where ductal hyperplasia or PanINs were also detected (54). It has been suggested that these lesions might be precursors of acinar cell carcinomas. However, there is a clear discrepancy between the number of observed lesions and the extremely rare incidence of acinar cell carcinoma.

In addition to cellular hyperplasia, two types of focal atypical acinar cell lesions associated with cigarette smoking have been described and differentiated by their staining properties in hematoxylin and eosin (H\&E) staining, one of which shows predominantly acidophilic cells, the other basophilic cells (55). Electron microscopy reveals dilated rough endoplasmic reticulum and few zymogen granules. Interestingly, the proliferative index was lower in these lesions than in adjacent normal pancreatic acini $(56,57)$. These acinar cell lesions were morphologically close to acinar cell nodules observed in rats treated with carcinogenic chemicals. However, their role remains speculative (58).

Cigarette smoking also induces the occurrence of atypical nuclei in pancreatic acinar and ductal cells, which were defined by variation in shape, size, and staining character. In pancreatic ducts, heavy smoking leads to an increase of atypical nuclei from 5.4 in non-smokers to $74.9 \%$ (59). Similarly, smoking 40 cigarettes per day induces an increase in atypical nuclei from 1.8 to $69.1 \%$. However, in contrast to acinar cell alterations, the increase in smoke related ductal lesions appears to correlate with age rather than with smoking history (60).

Similar to humans, rodents treated with environmental tobacco smoke also develop acinar cell damage (61). In this experiment, animals were exposed to environmental tobacco smoke for 70 min twice a day over a period of 3 months in two different doses, $100 \mathrm{mg} / \mathrm{m}^{3}$ total suspended particles (TSP) and $160 \mathrm{mg} / \mathrm{m}^{3}$ TSP. In $58 \%$ of the animals treated with the higher dose of cigarette smoke, histomorphologic pancreatic damage was detected, while animals subjected to the lower dose treatment lacked these lesions. The lesions were typically confined by sharp borders, which usually correlated with the anatomical lobular structures. They were also characterized by focal increases in extracellular matrices with a subsequent decrease in acinar cell structures (Fig. 1B). However, the occurrence of these lesions was low, and less than $5 \%$ of the pancreatic tissue was affected. Further examinations indicated that an inflammatory reaction was present and that the smoke-induced acinar cell damage may have induced chemotraction, immune responses, and tissue reorganization (62-64). 
A

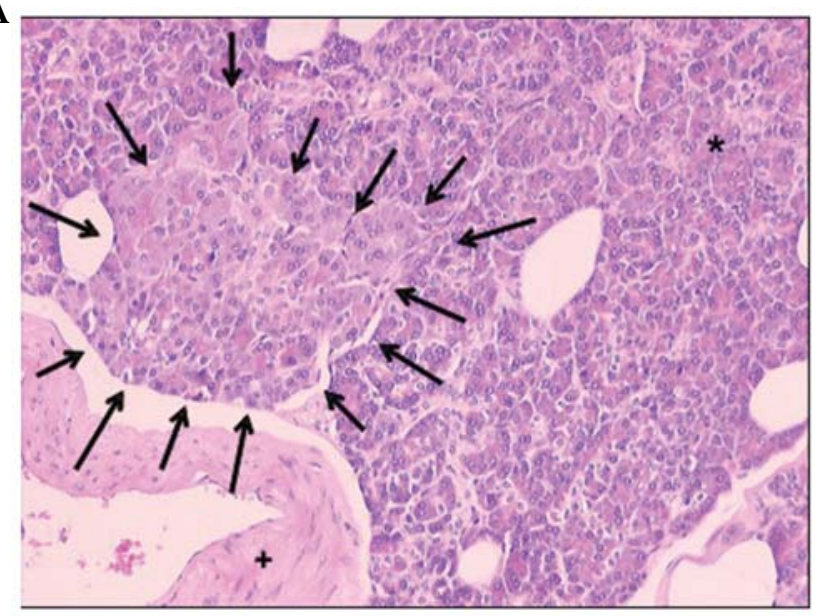

B

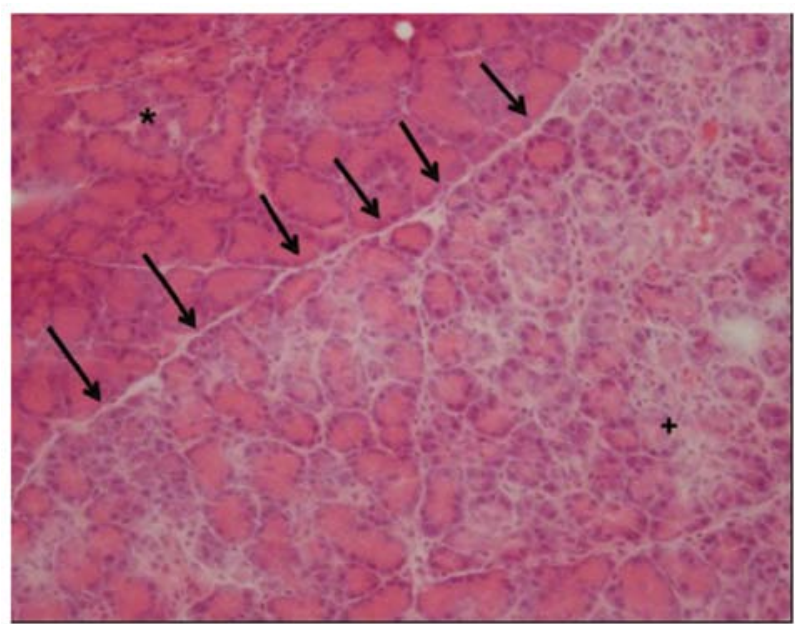

Figure 1. (A) Human acinar cell alterations in a tissue section-derived from a patient with pancreatic cancer. The arrows indicate the focal hyperplasia of acinar cells (asterisk) being well demarcated from normal acinar cells. A blood vessel (+) is shown in the lower left of the picture. H\&E, original magnification x100. (B) Section of the pancreas of a rat treated with cigarette smoke for 12 weeks. The arrows indicate focal acinar cell damage compared to normal acinar cells marked by an asterisk. Area of acinar cell damage is indicated by the cross. H\&E, original magnification x 200 .

\section{Enzyme regulation}

There is a clear association of cigarette smoke exposure and alterations of the pancreatic acinar cell compartment. Its pathomechanism and how acinar cell damage may contribute to the development of pancreatic ductal adenocarcinoma remain unclear. One probable causal factor is the ratio disturbance of pancreatic digestive enzyme expression and the expression of their protective, anti-proteolytic counterparts (65). Moreover, the impact of cigarette smoke is not limited to gene expression. Altered synthesis and secretion patterns are induced as well. Thus, trypsin and chymotrypsin activity of pancreatic cell lysates of animals exposed to cigarette smoke are markedly decreased (61).

Similar to the aforementioned experimental observations, smoking induces alterations of pancreatic enzyme synthesis and secretion in humans $(66,67)$. Current data must be interpreted carefully due to the small number of test subjects and distinct differences in the tests used. Still, it appears likely that cigarette smoking interferes with the synthesis and secretion of pancreatic digestive enzymes in humans. Upon pancreatic stimulation, increased serum concentrations of total amylase, pancreatic isoamylase, cationic trypsinogen, and pancreatic secretory trypsin inhibitor proteins were measured in cigarette smokers (68). Smokers more frequently showed a serum increase of immunoreactive cationic trypsinogen to secretin stimulation of more than $100 \%$ (69). However, a high dose of secretin was required to achieve a low response in blood enzyme concentration (70).

Additionally, secretin-independent increased basal levels of digestive enzymes in smokers have been reported. Basal serum amylase and pancreatic elastase concentrations were found to be higher in smokers than in non-smokers, and a single injection of secretin to cigarette smokers significantly increased serum amylase, trypsinogen and elastase without an observed increment in non-smokers (71). Similar results were found regarding serum lipase activity (72). These studies, together with the observation of altered gastrointestinal motility (67) and endo-

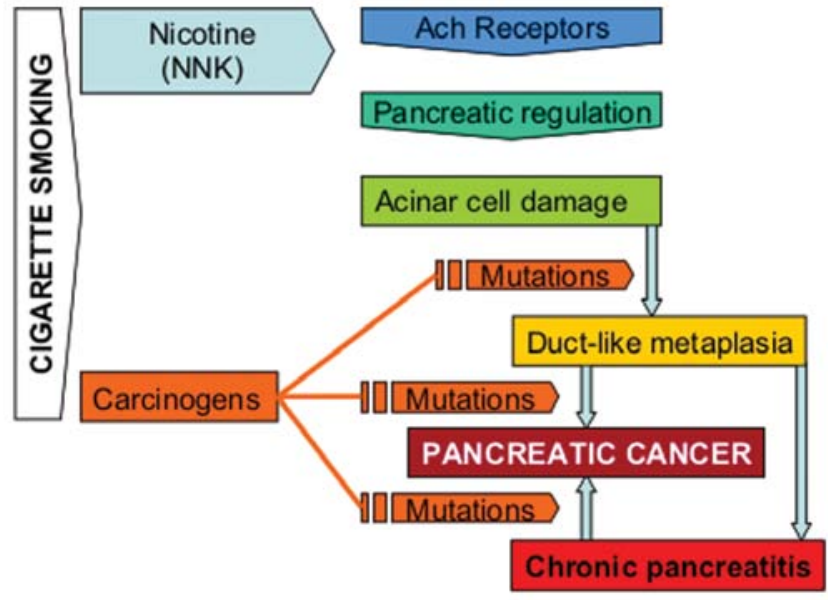

Figure 2. Schematic view of proposed mechanism of pancreatic cancer induction by cigarette smoke.

crine alterations $(73,74)$ indicate that cigarette smoking induces functional alterations of pancreatic enzyme secretion that are currently not fully understood.

\section{Nicotine and pancreatic regulation}

One pathophysiologial explanation for such altered secretion patterns could be the pharmacologic action of nicotine on the cholinergic system (75). In humans, pancreatic enzyme secretion is both under neurohormonal and CCK-receptor mediated control (76,77). In fact, there is a 10-fold higher level of m3-muscarinicreceptor-mRNA than CCK-receptor-mRNA. This indicates that the neurohormonal control of enzyme secretion plays a bigger role than acinar cell stimulation with CCK (78).

Several studies examined the action of nicotine on the pancreatic gland. Biologically active nicotine and its inactive metabolites cotinine and norcotinine can be detected in the pancreas. In vitro pancreatic stimulation even increases acinar cell uptake of nicotine $(61,79,80)$. The pathophysiological 
action of nicotine on the pancreas has been reviewed recently $(79,81,82)$. In rodents, nicotine induces a widespread action on acinar cells. After adding nicotine to the drinking water of rats in concentrations ranging from $50-200 \mathrm{mg} / \mathrm{l}$ over a period of 16 weeks, acinar cell amylase release upon CCK-8 stimulation is decreased (83). This effect appears to occur in vivo as well where pancreatic secretion is reduced while transcription of digestive enzymes remains unaltered, leading to increased pancreatic content of digestive enzymes upon nicotine treatment (84). Furthermore, nicotine induces morphological and functional cell lesions regardless of the application method $(83,85,86)$.

Interestingly, nicotine also increases acinar cell proliferation in AR42J cells, an immortal cell line-derived from acinar cells with retained secretory capacity (81). This proliferative effect was dependent on p-ERK 1/2 activation, but neither ERK activation nor cell proliferation was truncated by the $\mathrm{nAChR}$ antagonist mecamylamine, indicating this effect being independent of nicotinic acetylcholine receptors (nAChR) (87). In freshly isolated pancreatic acini, a similar proliferative response upon nicotine treatment was observed. However, in contrast to AR42J cells, this response was mediated by interaction of nicotine with $\mathrm{nAChRs}$ and b-ARs (88).

While the data on nicotinic action in pancreatic cells are limited, the effect of nicotine has been investigated in greater detail in other types of tissue. In these studies, nicotine exerted an effect on a variety of human cell types such as endothelial cells and even tumor cells (89). There is a plethora of experimental evidence demonstrating various effects of nicotine, such as an increased survival of tumor cells (90), an increased rate of tumor metastasis $(91,92)$, a decrease in patient survival (93-95), and a reduced response to chemotherapy (96-100).

One of the nicotine-related effects that was studied in detail, is the angiogenic property of nicotine which is mediated at least in part by nAChRs (101-103). The endothelial cell tube formation assay using human umbilical vein cells (HUVEC) showed that nicotine stimulated the release of basic fibroblast growth factor (b-FGF) in HUVECS (104). In accordance, nicotine treatment increased human endothelial cell tube formation in a dosedependent manner. Similarly, nicotine stimulated angiogenesis through b-FGF in the chick chorioallantoic membrane (CAM) tumor implant model. These effects were completely blocked by $\alpha v \beta 3$ integrin antibodies and by the blockade of the non-neuronal nicotine receptor, indicating that FGF and nACh-receptors are involved in nicotine mediated angiogenesis (103).

In cervical cancer cell lines, nicotine induces increased cell proliferation and EGFR over-expression (105). Furthermore, after serum starvation, long-term exposure of mouse epithelial lung cells to nicotine disrupted the cell cycle restriction machinery in a nAChR-dependent manner through ras activation and subsequent increase in Raf/MAP kinase activity, which further induced a significant increase in cyclin D1 promoter activity (106). Intriguingly, significant differences were observed between short- and long-term exposure of immortal cell lines to nicotine. While brief nicotine application induces protein kinase $\mathrm{C}$ and phosphoinositide 3-OH-kinase activation, long-term exposure influenced ras activation and ERK 1/2 expression (107). In parallel to increasing proliferation, nicotine also reduces the rate of apoptosis by NF- $\mathrm{KB}$ up-regulation (108). These observations were reproduced in vivo where nicotine treatment stimulated the growth of pancreatic xenograft tumors (109). Taking the above- mentioned experimental evidence into consideration, it appears without a doubt that nicotine alters neurotransmitter levels in pancreatic cancer, exerts direct proliferative effects on tumor cells and increases neo-angiogenesis (110).

\section{Cigarette smoke-related carcinogens and the pancreatic gland}

In cigarette smoke, many substances have been detected that directly induce malignant tumors through DNA interference. Several of these compounds have been proven to reach the pancreas and are likely to influence carcinogenesis. In a study examining the carcinogenic burden of the pancreatic juice of 18 smokers and 9 non-smokers, the mean level of the nicotine derivative 4-(methylnitrosamino)-1-(3-pyridyl)-1-butanone (NNK), a nitrosamine (111), smoking significantly elevated the NNK concentration in pancreatic juice. Another nicotine derivative, N'-nitrosonornicotine (NNN), was found in two out of 18 samples of the pancreatic juice of smokers, and 4-(methylnitrosamino)-1-(3-pyridyl)-1-butanol (NNAL) was detected more frequently as well (112).

In rodents several tobacco-derived carcinogens have been found to induce pancreatic tumors of ductal phenotype (Table I). NNK and NNAL, a carbonyl reduction metabolite of NNK, induces pancreatic tumors in mice, rats and in hamsters. In $10 \%$ of F344 rats, life-time treatment with 1 ppm NNK in the drinking water induced pancreatic tumors of ductal phenotype. Strikingly, lung tumors were observed in $25 \%$ (113). The tumorigenicity was diet-dependent and increased in animals with high fat intake. However, F344 rats tend to develop spontaneous pancreatic tumors with increasing age independent of their diet which indicates that the diet accelerated tumor formation (114).

The formation of DNA adducts and their subsequent interference with gene function plays a key role in carcinogenesis. Cigarette smoking increases these DNA adducts in the human pancreas. In a ${ }^{32} \mathrm{P}$ post-labeling analysis of pancreatic DNA of smokers $102 \pm 21$ DNA adducts $/ 10^{8}$ nucleotides were detected. This contrasts sharply with the ${ }^{32} \mathrm{P}$-post-labeling analysis of DNA-derived from non-smoking control subjects which reveals only $13 \pm 1$ DNA adducts $/ 10^{8}$ nucleotides (115). The chemical nature of these adducts found in human smokers is heterogeneous, and there is no evidence that one specific DNA adduct is induced by cigarette smoking. One possible explanation may be that nitrosamines are metabolized to reactive electrophils in order to react with DNA, and this metabolic process may be influenced by individual and organ specific factors $(116,117)$. In laboratory animals, carcinogen metabolization has been extensively studied, and it has been found that the hydroxylation of NNK by cytochrome P450 isoenzymes induces DNA methylation (118). Additional experiments showed that unspecific inhibition of NNK hydroxylation through isothiocyanate inhibits the generation of NNAL and decreases its carcinogenic potential $(119,120)$. Whether these mechanisms are solely responsible for the tumor formation is a matter of debate, and several studies propose additional mechanisms of NNK action. The observation that DNA methylation patterns in rats, mice, and hamsters did not correlate with the organotropy of NNK mediated carcinogenesis corroborates this view (121). A second observation supporting additional factors to the $\mathrm{P} 450$ catalysed $\alpha$ hydroxylation in NNK-induced tumorigenesis is the influence of ethanol treat- 
Table I. In vitro and in vivo action of tobacco-derived carcinogens (A acinar phenotype; D, ductal phenotype; $\mathrm{P}$, precancerous lesion).

\begin{tabular}{|c|c|c|c|}
\hline Carcinogen & $\begin{array}{l}\text { Tumorigenic } \\
\text { in pancreas }\end{array}$ & $\begin{array}{c}\text { Detected in } \\
\text { human pancreas }\end{array}$ & $\begin{array}{c}\text { Increased DNA } \\
\text { adducts in smokers }\end{array}$ \\
\hline
\end{tabular}

4-(methylnitrosamino)-1-(3-pyridyl)-1-butanone (NNK) Rats D (113) Pancreatic juice
NNAL
NNAL

N-nitroso-bis(2-oxopropyl)amine (BOP)

N-nitroso-bis(2-hydroxypropyl)amine (BHP)

$\mathrm{N}$-nitroso-(2-hydroxypropyl)(2-oxopropyl)amine (HPOP)

$\mathrm{N}$-nitroso-bis(2-acetoxypropyl)amine (BAP)

7,12-dimethyl-1,2-benzanthracene (DMBA)

3-methylcholanthrene (3-MC)

N-nitroso-2,6-dimethylmorpholine (cis-NNDM)

N-nitrosomethyl(2-oxopropyl)amine (MOP)

n-methyl-N-nitrosourea (MNU)

2-amino-1-methyl-6-phenylimidazo [4,5-b]-pyridine (PhIP)

\author{
Hamsters D \\ $(148,167)$ \\ (168)
}

Mouse D

(153) Rat D

(169)

Hamsters D

Rat D (171)

Hamster D $(168,172)$

Hamster D (173)

Mouse P (174)

Guinea Pig D/P (175)
No No

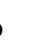

(2) 
and c-Myc in promoting cell survival and proliferation, while at the same time the cell migration and invasion was increased in an Erk1/2-dependent manner $(146,147)$.

Other tobacco-derived carcinogens, such as N-nitrosobis(2-oxopropyl)amine (BOP) applied subcutaneously, can induce pancreatic adenocarcinomas in an experimental setting. Co-treatment with NNAL induced a synergistic, carcinogenic action (148-151).

Furthermore, dimethylbenzanthracene (DMBA) induces pancreatic tumors in rodents and resembles a model in which transdifferentional events in pancreatic carcinogenesis may play a role. When DMBA crystals are implanted in the area of the pancreatic head of mice, these mice quickly develop pancreatic duct alterations in a Notch signalling-dependent manner (152). These changes are characterized by transdifferentiation of acinar cells to tubular lesions starting as early as 2 weeks after DMBA implantation. One month post-implantation, PanIN lesions and some adenocarcinomas were observed. Sixty percent of the animals developed pancreatic tumors within three months after implantation $(152,153)$. Intriguingly, DMBA induces pancreatic carcinogenesis in rats as well $(58,154,155)$. DMBA-induced carcinogenesis was increased through pancreatic hyperstimulation as well as systemic immunosuppression through immunosuppressive acidic protein $(156,157)$. Metabolization of DMBA has been investigated in rats. High concentrations of DMBA metabolites, such as 5,6-epoxy-7-hydroxymethyl12-methylbenzanthracene were formed by pancreatic tissue in vitro, and measured DMBA-DNA adducts correlated with tumorigenesis in F344 rats (158).

\section{Acinar cell damage and pancreatic ductal adenocarcinoma}

It seems that cigarette smoke as well as the DMBA model primarily affect the acinar cell compartment. This appears to be in contrast to the ductal phenotype of human pancreatic cancer. Experimental evidence suggests that cigarette smoke exposure induces a differential expression of genes related to pancreatic ducts only when histomorphological acinar cell damage is present (65). Recent data on carcinogen-induced transformation of acinar cells to atypical pseudo-ductular structures in the DMBA model indicate that neither centroacinar cells nor pancreatic ductal cells are the only progenitors from which the pancreatic ductal adenocarcinoma develops $(58,159,160)$. In genetic mouse models of K-ras, nestin positive progenitor cells were the source of ductal adenocarcinomas (161). Nestin is expressed in both endocrine and exocrine lineages. In additional experiments the selective expression of endogenous K-ras oncogene in embryonic acinar cells and in the centroacinar lineage resulted in pancreatic intraepithelial neoplasias and invasive pancreatic ductal adenocarcinoma $(162,163)$. However, since nestin is not expressed in cells of the centroacinar lineage and since beta cell transdifferentiation does not contribute to metaplastic ductal lesions, the possibility of acinar to ductal transdifferentiation in early pancreatic carcinogenesis became likely (164). In accord with this hypothesis, Cre-loxP-based genetic lineage tracing provides direct evidence of acinar to ductal metaplasia in a minority of mucinous metaplastic lesions induced by pancreatic hyperstimulation (165). Independently, acinar cell targeting of oncogenic K-ras in adult mice induces a spontaneous induction of mPanINs of all histological grades
(166). Therefore, if transdifferentiation of acinar cells to ductlike structures is thus induced, acinar cell damage may be the fist step in cigarette smoke-induced pancreatic adenocarcinoma.

\section{Conclusions and perspectives}

Cigarette smoke inhalation leads to pancreatic acinar cell damage and increases the risk of developing pancreatic cancer and chronic pancreatitis in humans. So far, the precise underlying mechanisms have not been defined. The influence of cigarette smoke constituents on pancreatic carcinogenesis can be divided into two major modes of action, first through the interference with physiological pathways and second through the interaction with DNA. Nicotine and its derivatives greatly interfere with physiological regulatory pathways in terms of altering secretion, increasing proliferation and reducing apoptosis. These alterations result in inflammatory lesions to pancreatic acinar cells. The second class of substances that induces pancreatic carcinogenesis interferes with pancreatic DNA. The data reviewed strongly suggest that cigarette smoke induced pancreatic carcinogenesis is a multifactorial event consisting of DNA damage as well as DNA independent alterations. Of these events, the transdifferentiation of acinar cells to duct-like structures may be the link between cigarette smoke induced acinar cell damage and the development of ductal adenocarcinoma. Additionally, tobaccoderived carcinogens may cause genomic mutations that lead to a malignant phenotype (Fig. 2). Further studies that are not limited to acinar or ductal cells are therefore needed to investigate the pathogenesis of cigarette smoke induced pancreatic damage.

\section{Acknowledgements}

The authors (S.K.B. and N.M.) on this work are supported by grants from the National Institutes of Health (CA78590, CA133774 and CA13194).

\section{References}

1. Parkin DM, Bray F, Ferlay J and Pisani P: Global cancer statistics, 2002. CA Cancer J Clin 55: 74-108, 2005.

2. Lowenfels AB and Maisonneuve P: Risk factors for pancreatic cancer. J Cell Biochem 95: 649-656, 2005.

3. Bray F, Sankila R, Ferlay J and Parkin DM: Estimates of cancer incidence and mortality in Europe in 1995. Eur J Cancer 38: 99-166, 2002.

4. Ries LAG, Harkins D, Krapcho M, et al: SEER Cancer Statistics Review, 1975-2003, National Cancer Institute. Bethesda, MD, USA. Section 22, pp5-6, 2006.

5. Michaud DS: Epidemiology of pancreatic cancer. Minerva Chir 59: 99-111, 2004.

6. Everhart J and Wright D: Diabetes mellitus as a risk factor for pancreatic cancer. A meta-analysis. JAMA 273: 1605-1609, 1995.

7. Silverman DT, Schiffman M, Everhart J, et al: Diabetes mellitus, other medical conditions and familial history of cancer as risk factors for pancreatic cancer. Br J Cancer 80: 1830-1837, 1999.

8. Hennig R, Ding XZ and Adrian TE: On the role of the islets of Langerhans in pancreatic cancer. Histol Histopathol 19: 999-1011, 2004.

9. Wang F, Gupta S and Holly EA: Diabetes mellitus and pancreatic cancer in a population-based case-control study in the San Francisco Bay Area, California. Cancer Epidemiol Biomarkers Prev 15: 1458-1463, 2006.

10. Chari ST, Leibson CL, Rabe KG, Timmons LJ, Ransom J, de Andade $M$ and Petersen GM: Pancreatic cancer-associated diabetes mellitus: prevalence and temporal association with diagnosis of cancer. Gastroenterology 134: 95-101, 2008. 
11. Pannala R, Leirness JB, Bamlet WR, Basu A, Petersen GM and Chari ST: Prevalence and clinical profile of pancreatic cancerassociated diabetes mellitus. Gastroenterology 134: 981-987, 2008.

12. Pannala R, Basu A, Petersen GM and Chari ST: New-onset diabetes: a potential clue to the early diagnosis of pancreatic cancer. Lancet Oncol 10: 88-95, 2009.

13. Kolb A, Rieder S, Born D, et al: Glucagon/insulin ratio as a potential biomarker for pancreatic cancer in patients with new-onset diabetes mellitus. Cancer Biol Ther 8: 1527-1533, 2009.

14. Stevens RJ, Roddam AW and Beral V: Pancreatic cancer in type 1 and young-onset diabetes: systematic review and meta-analysis. Br J Cancer 96: 507-509, 2007.

15. Stolzenberg-Solomon RZ, Graubard BI, Chari S, Limburg P, Taylor PR, Virtamo J and Albanes D: Insulin, glucose, insulin resistance, and pancreatic cancer in male smokers. JAMA 294 2872-2878, 2005.

16. Rousseau MC, Parent ME, Pollak MN and Siemiatycki J: Diabetes mellitus and cancer risk in a population-based case-control study among men from Montreal, Canada. Int J Cancer 118: 2105-2109, 2006.

17. Chari ST, Leibson CL, Rabe KG, Ransom J, de Andrade M and Petersen GM: Probability of pancreatic cancer following diabetes: a population-based study. Gastroenterology 129: 504-511, 2005.

18. Larsson SC, Orsini N and Wolk A: Body mass index and pancreatic cancer risk: a meta-analysis of prospective studies. Int J Cancer 120: 1993-1998, 2007.

19. Lin Y, Kikuchi S, Tamakoshi A, et al: Obesity, physical activity and the risk of pancreatic cancer in a large Japanese cohort. Int J Cancer 120: 2665-2671 2007.

20. Rapp K, Schroeder J, Klenk J, et al: Obesity and incidence of cancer: a large cohort study of over 145,000 adults in Austria. Br J Cancer 93: 1062-1067, 2005.

21. Larsson SC, Permert J, Hakansson N, Naslund I, Bergkvist L and Wolk A: Overall obesity, abdominal adiposity, diabetes and cigarette smoking in relation to the risk of pancreatic cancer in two Swedish population-based cohorts. Br J Cancer 93: 1310-1315, 2005.

22. Nothlings U, Wilkens LR, Murphy SP, Hankin JH, Henderson BE and Kolonel LN: Body mass index and physical activity as risk factors for pancreatic cancer: the Multiethnic Cohort Study. Cancer Causes Control 18: 165-175, 2007.

23. Lee IM, Sesso HD, Oguma Y and Paffenbarger RS Jr: Physical activity, body weight, and pancreatic cancer mortality. Br J Cancer 88: 679-683, 2003

24. Khurana V, Sheth A, Caldito G and Barkin JS: Statins reduce the risk of pancreatic cancer in humans: a case-control study of half a million veterans. Pancreas 34: 260-265, 2007.

25. Li D, Yeung SC, Hassan MM, Konopleva M and Abbruzzese JL: Antidiabetic therapies affect risk of pancreatic cancer. Gastroenterology 137: 482-488, 2009.

26. Malka D, Hammel P, Maire F, et al: Risk of pancreatic adenocarcinoma in chronic pancreatitis. Gut 51: 849-852, 2002.

27. Talamini G, Falconi M, Bassi C, et al: Incidence of cancer in the course of chronic pancreatitis. Am J Gastroenterol 94: 1253-1260, 1999.

28. Lowenfels AB, Maisonneuve P, Cavallini G, et al: Pancreatitis and the risk of pancreatic cancer. International Pancreatitis Study Group. N Engl J Med 328: 1433-1437, 1993.

29. Lowenfels AB, Maisonneuve P, DiMagno EP, Elitsur Y, Gates LK Jr, Perrault $\mathbf{J}$ and Whitcomb DC: Hereditary pancreatitis and the risk of pancreatic cancer. International Hereditary Pancreatitis Study Group. J Natl Cancer Inst 89: 442-446, 1997.

30. Chari ST, Mohan V, Pitchumoni CS, Viswanathan M, Madanagopalan N and Lowenfels AB: Risk of pancreatic carcinoma in tropical calcifying pancreatitis: an epidemiologic study. Pancreas 9: 62-66, 1994.

31. Greer JB and Whitcomb DC: Inflammation and pancreatic cancer: an evidence-based review. Curr Opin Pharmacol 9: 411-418, 2009.

32. Lowenfels AB and Maisonneuve P: Epidemiology and risk factors for pancreatic cancer. Best Pract Res Clin Gastroenterol 20 197-209, 2006

33. Klein AP, Brune KA, Petersen GM, et al: Prospective risk of pancreatic cancer in familial pancreatic cancer kindreds. Cancer Res 64: 2634-2638, 2004.

34. Greer JB and Whitcomb DC: Role of BRCA1/2 mutations in pancreatic cancer. Gut 56: 601-605, 2006.

35. Hahn SA, Greenhalf B, Ellis I, et al: BRCA2 germline mutations in familial pancreatic carcinoma. J Natl Cancer Inst 95: 214-221, 2003.
36. Couch FJ, Johnson MR, Rabe KG, et al: The prevalence of BRCA2 mutations in familial pancreatic cancer. Cancer Epidemiol Biomarkers Prev 16: 342-346, 2007.

37. Habbe N, Langer P, Sina-Frey M and Bartsch DK: Familial pancreatic cancer syndromes. Endocrinol Metab Clin North Am 35: 417-430, xi, 2006.

38. Pogue-Geile KL, Chen R, Bronner MP, et al: Palladin mutation causes familial pancreatic cancer and suggests a new cancer mechanism. PLoS Med 3: e516, 2006.

39. Bradbury J: Familial pancreatic-cancer gene found. Lancet Oncol 8: 14,2007

40. Patel AV, Rodriguez C, Bernstein L, Chao A, Thun MJ and Calle EE: Obesity, recreational physical activity, and risk of pancreatic cancer in a large U.S. Cohort. Cancer Epidemiol Biomarkers Prev 14: 459-466, 2005.

41. Qiu D, Kurosawa M, Lin Y, et al: Overview of the epidemiology of pancreatic cancer focusing on the JACC Study. J Epidemiol 15 (Suppl. 2): S157-S167, 2005.

42. Fuchs CS, Colditz GA, Stampfer MJ, et al: A prospective study of cigarette smoking and the risk of pancreatic cancer. Arch Intern Med 156: 2255-2260, 1996.

43. Yun JE, Jo I, Park J, et al: Cigarette smoking, elevated fasting serum glucose, and risk of pancreatic cancer in Korean men. Int J Cancer 119: 208-212, 2006.

44. IARC: Tobacco smoke and involuntary smoking. Lyon, France, 83: 1187, 2004

45. Rulyak SJ, Lowenfels AB, Maisonneuve P and Brentnall TA: Risk factors for the development of pancreatic cancer in familial pancreatic cancer kindreds. Gastroenterology 124: 1292-1299, 2003.

46. Lowenfels AB, Maisonneuve P and Whitcomb DC: Risk factors for cancer in hereditary pancreatitis. International Hereditary Pancreatitis Study Group. Med Clin North Am 84: 565-573, 2000

47. Lin Y, Tamakoshi A, Hayakawa T, Ogawa M and Ohno Y: Cigarette smoking as a risk factor for chronic pancreatitis: a case-control study in Japan. Research Committee on Intractable Pancreatic Diseases. Pancreas 21: 109-114, 2000.

48. Yadav D, Hawes RH, Brand RE, et al: Alcohol consumption, cigarette smoking, and the risk of recurrent acute and chronic pancreatitis. Arch Intern Med 169: 1035-1045, 2009.

49. Maisonneuve P, Lowenfels AB, Mullhaupt B, et al: Cigarette smoking accelerates progression of alcoholic chronic pancreatitis. Gut 54: 510-514, 2005.

50. Maisonneuve P, Frulloni L, Mullhaupt B, Faitini K, Cavallini G, Lowenfels AB and Ammann RW: Impact of smoking on patients with idiopathic chronic pancreatitis. Pancreas 33: 163-168, 2006.

51. Maisonneuve P and Lowenfels AB: Chronic pancreatitis and pancreatic cancer. Dig Dis 20: 32-37, 2002.

52. Tobacco related exposures. In: Report on Carcinogens. 11th edition. US Department of Health and Human Services, Public Health Service, National Toxicology Program, 2005.

53. Longnecker DS, Shinozuka H and Dekker A: Focal acinar cell dysplasia in human pancreas. Cancer 45: 534-540, 1980.

54. Kishi K, Nakamura K, Yoshimori M, et al: Morphology and pathological significance of focal acinar cell dysplasia of the human pancreas. Pancreas 7: 177-182, 1992

55. Tanaka T, Mori H and Williams GM: Atypical and neoplastic acinar cell lesions of the pancreas in an autopsy study of Japanese patients. Cancer 61: 2278-2285, 1988.

56. Fang J, Hussong J, Roebuck BD, Talamonti MS and Rao MS: Atypical acinar cell foci in human pancreas. Morphological and morphometric analysis. Int J Pancreatol 22: 127-130, 1997.

57. Shinozuka H, Lee RE, Dunn JL and Longnecker DS: Multiple atypical acinar cell nodules of the pancreas. Hum Pathol 11: 389-391, 1980

58. Bockman DE, Guo J, Buchler P, Muller MW, Bergmann F and Friess H: Origin and development of the precursor lesions in experimental pancreatic cancer in rats. Lab Invest 83: 853-859, 2003.

59. Auerbach $\mathrm{O}$ and Garfinkel L: Histologic changes in pancreas in relation to smoking and coffee-drinking habits. Dig Dis Sci 31: 1014-1020, 1986.

60. Tomioka T, ndren-Sandberg A, Fujii H, Egami H, Takiyama Y and Pour PM: Comparative histopathological findings in the pancreas of cigarette smokers and non-smokers. Cancer Lett 55 121-128, 1990.

61. Wittel UA, Pandey KK, Andrianifahanana M, et al: Chronic pancreatic inflammation induced by environmental tobacco smoke inhalation in rats. Am J Gastroenterol 101: 148-159, 2006. 
62. Shi MM, Chong IW, Long NC, Love JA, Godleski JJ and Paulauskis JD: Functional characterization of recombinant rat macrophage inflammatory protein-1 alpha and mRNA expression in pulmonary inflammation. Inflammation 22: 29-43, 1998.

63. Rau B, Paszkowski A, Lillich S, Baumgart K, Moller P and Beger HG: Differential effects of caspase-1/interleukin-1betaconverting enzyme on acinar cell necrosis and apoptosis in severe acute experimental pancreatitis. Lab Invest 81: 1001-1013, 2001.

64. Rane SG, Lee JH and Lin HM: Transforming growth factor-beta pathway: role in pancreas development and pancreatic disease. Cytokine Growth Factor Rev 17: 107-119, 2006.

65. Wittel UA, Singh AP, Henley BJ, Andrianifahanana M, Akhter MP, Cullen DM and Batra SK: Cigarette smoke-induced differential expression of the genes involved in exocrine function of the rat pancreas. Pancreas 33: 364-370, 2006.

66. Bynum TE, Solomon TE, Johnson LR and Jacobson ED: Inhibition of pancreatic secretion in man by cigarette smoking. Gut 13 : 361-365, 1972.

67. Demol P, Singer MV,Hotz J,Dipp M and Goebell H: Interdigestive gastrointestinal motility and secretion of gastric acid and pancreatic enzymes in young cigarette smokers. Digestion 29: 107-111, 1984

68. Balldin G, Borgstrom A, Eddeland A, Genell S, Hagberg L and Ohlsson K: Elevated serum levels of pancreatic secretory proteins in cigarette smokers after secretin stimulation. J Clin Invest 66: 159-162, 1980.

69. Andriulli A, Masoero G, Amato A, et al: Serum immunoreactive cationic trypsinogen response to secretin in normal subjects. Am J Gastroenterol 78: 579-583, 1983.

70. Munch R, Kehl O, Buhler H, Medici T and Ammann R: [Changes in the serum pancreas enzyme following i.v. stimulation with secretin in subjects with a normal pancreas]. Schweiz Med Wochenschr 117: 756-760, 1987.

71. Dubick MA, Conteas CN, Billy HT, Majumdar AP and Geokas MC: Raised serum concentrations of pancreatic enzymes in cigarette smokers. Gut 28: 330-335, 1987.

72. Sliwinska-Mosson M and Milnerowicz H: [Influence of tobacco smoking on lipase activity in patients with pancreatitis]. Przeg Lek 62: 1058-1061, 2005.

73. Borissova AM, Tankova T, Kirilov G, Dakovska L and Krivoshiev S: The effect of smoking on peripheral insulin sensitivity and plasma endothelin level. Diabetes Metab 30: 147-152, 2004.

74. Milnerowicz H, Sliwinska-Mosson M, Rabczynski J, Nowak M and Milnerowicz S: Dysfunction of the pancreas in healthy smoking persons and patients with chronic pancreatitis. Pancreas 34: 46-54, 2007.

75. Owyang $\mathrm{C}$ and Logsdon CD: New insights into neurohormonal regulation of pancreatic secretion. Gastroenterology 127: 957-969, 2004.

76. Saluja A, Logsdon C and Garg P: Direct versus indirect action of cholecystokinin on human pancreatic acinar cells: is it time for a judgment after a century of trial? Gastroenterology 135: 357-360, 2008 .

77. Murphy JA, Criddle DN, Sherwood M, et al: Direct activation of cytosolic $\mathrm{Ca}^{2+}$ signaling and enzyme secretion by cholecystokinin in human pancreatic acinar cells. Gastroenterology 135: 632-641, 2008

78. Samuel I, Zaheer A, Zaheer S and Fisher RA: Bile-pancreatic juice exclusion increases cholinergic M3 and CCK-A receptor expression and interleukin-6 production in ligation-induced acute pancreatitis. Am J Surg 188: 511-515, 2004.

79. Chowdhury P, MacLeod S, Udupa KB and Rayford PL: Pathophysiological effects of nicotine on the pancreas: an update. Exp Biol Med 227: 445-454, 2002.

80. Doi R, Chowdhury P, Nishikawa M, Takaori K, Inoue K, Imamura $\mathrm{M}$ and Rayford PL: Carbachol and cholecystokinin enhance accumulation of nicotine in rat pancreatic acinar cells. Pancreas 10: 154-160, 1995.

81. Chowdhury P and Udupa KB: Nicotine as a mitogenic stimulus for pancreatic acinar cell proliferation. World J Gastroenterol 12 : 7428-7432, 2006

82. Chowdhury P and Walker A: A cell-based approach to study changes in the pancreas following nicotine exposure in an anima model of injury. Langenbecks Arch Surg 393: 547-555, 2008.

83. Chowdhury P, Doi R, Tangoku A and Rayford PL: Structural and functional changes of rat exocrine pancreas exposed to nicotine. Int J Pancreatol 18: 257-264, 1995.
84. Lindkvist B, Wierup N, Sundler F and Borgstrom A: Long-term nicotine exposure causes increased concentrations of trypsinogens and amylase in pancreatic extracts in the rat. Pancreas 37 288-294, 2008

85. Chowdhury P, Hosotani R and Rayford PL: Inhibition of CCK or carbachol-stimulated amylase release by nicotine. Life Sci 45 2163-2168, 1989

86. Lau PP, Dubick MA, Yu GS, Morrill PR and Geokas MC: Dynamic changes of pancreatic structure and function in rats treated chronically with nicotine. Toxicol Appl Pharmacol 104 457-465, 1990.

87. Bose C, Zhang H, Udupa KB and Chowdhury P: Activation of p-ERK1/2 by nicotine in pancreatic tumor cell line AR42J: effects on proliferation and secretion. Am J Physiol Gastrointest Liver Physiol 289: G926-G934, 2005.

88. Chowdhury P, Bose $\mathrm{C}$ and Udupa KB: Nicotine-induced proliferation of isolated rat pancreatic acinar cells: effect on cell signalling and function. Cell Prolif 40: 125-141, 2007.

89. Dasgupta P, Rizwani W, Pillai S, et al: Nicotine induces cell proliferation, invasion and epithelial-mesenchymal transition in a variety of human cancer cell lines. Int J Cancer 124: 36-45, 2009.

90. Carlisle DL, Liu X, Hopkins TM, Swick MC, Dhir R and Siegfried JM: Nicotine activates cell-signaling pathways through muscle-type and neuronal nicotinic acetylcholine receptors in non-small cell lung cancer cells. Pulm Pharmacol Ther 20: 629-641, 2007.

91. Murin S and Inciardi J: Cigarette smoking and the risk of pulmonary metastasis from breast cancer. Chest 119: 1635-1640, 2001.

92. Scanlon EF, Suh O, Murthy SM, Mettlin C, Reid SE and Cummings KM: Influence of smoking on the development of lung metastases from breast cancer. Cancer 75: 2693-2699, 1995.

93. Calle EE, Miracle-McMahill HL, Thun MJ and Heath CW Jr: Cigarette smoking and risk of fatal breast cancer. Am J Epidemio 139: 1001-1007, 1994

94. Manjer J, Andersson I, Berglund G, et al: Survival of women with breast cancer in relation to smoking. Eur J Surg 166 $852-858,2000$

95. Yancik R, Wesley MN, Ries LA, Havlik RJ, Edwards BK and Yates JW: Effect of age and comorbidity in postmenopausal breast cancer patients aged 55 years and older. JAMA 285 885-892, 2001 .

96. Videtic GM, Stitt LW, Dar AR, et al: Continued cigarette smoking by patients receiving concurrent chemoradiotherapy for limited-stage small-cell lung cancer is associated with decreased survival. J Clin Oncol 21: 1544-1549, 2003.

97. Volm M, Samsel B and Mattern J: Relationship between chemoresistance of lung tumours and cigarette smoking. Br J Cancer 62: 255-256, 1990.

98. Browman GP, Wong G, Hodson I, et al: Influence of cigarette smoking on the efficacy of radiation therapy in head and neck cancer. N Engl J Med 328: 159-163, 1993.

99. Chelghoum Y, Danaila C, Belhabri A, et al: Influence of cigarette smoking on the presentation and course of acute myeloid leukemia. Ann Oncol 13: 1621-1627, 2002.

100. Johnston-Early A, Cohen MH, Minna JD, et al: Smoking abstinence and small cell lung cancer survival. An association. JAMA 244: 2175-2179, 1980

101. Costa F and Soares R: Nicotine: a pro-angiogenic factor. Life Sci 84: 785-790, 2009.

102. Heeschen C, Chang E, Aicher A and Cooke JP: Endothelial progenitor cells participate in nicotine-mediated angiogenesis. J Am Coll Cardiol 48: 2553-2560, 2006.

103. Mousa S and Mousa SA: Cellular and molecular mechanisms of nicotine's pro-angiogenesis activity and its potential impact on cancer. J Cell Biochem 97: 1370-1378, 2006.

104. Park YJ, Lee T, Ha J, Jung IM, Chung JK and Kim SJ: Effect of nicotine on human umbilical vein endothelial cells (HUVECs) migration and angiogenesis. Vascul Pharmacol 49: 32-36, 2008.

105. Mathur RS, Mathur SP and Young RC: Up-regulation of epidermal growth factor-receptors (EGF-R) by nicotine in cervical cancer cell lines: this effect may be mediated by EGF. Am J Reprod Immunol 44: $114-120,2000$

106. Chu M, Guo J and Chen CY: Long-term exposure to nicotine, via ras pathway, induces cyclin D1 to stimulate G1 cell cycle transition. J Biol Chem 280: 6369-6379, 2005. 
107. Guo J, Chu M, Abbeyquaye T and Chen CY: Persistent nicotine treatment potentiates amplification of the dihydrofolate reductase gene in rat lung epithelial cells as a consequence of Ras activation. J Biol Chem 280: 30422-30431, 2005.

108. Zhang T, Lu H, Shang X, et al: Nicotine prevents the apoptosis induced by menadione in human lung cancer cells. Biochem Biophys Res Commun 342: 928-934, 2006.

109. Al-Wadei HA, Plummer HK III and Schuller HM: Nicotine stimulates pancreatic cancer xenografts by systemic increase in stress neurotransmitters and suppression of the inhibitory neurotransmitter gamma-aminobutyric acid. Carcinogenesis 30 : 506-511, 2009.

110. Al-Wadei HA and Schuller HM: Nicotinic receptor-associated modulation of stimulatory and inhibitory neurotransmitters in NNK-induced adenocarcinoma of the lungs and pancreas. J Pathol 218: 437-445, 2009.

111. Hecht SS, Chen CB, Hirota N, Ornaf RM, Tso TC and Hoffmann D Tobacco-specific nitrosamines: formation from nicotine in vitro and during tobacco curing and carcinogenicity in strain A mice. J Natl Cancer Inst 60: 819-824, 1978.

112. Prokopczyk B, Hoffmann D, Bologna M, et al: Identification of tobacco-derived compounds in human pancreatic juice. Chem Res Toxicol 15: 677-685, 2002.

113. Rivenson A, Hoffmann D, Prokopczyk B, Amin S and Hecht SS: Induction of lung and exocrine pancreas tumors in F344 rats by tobacco-specific and Areca-derived N-nitrosamines. Cancer Res 48: 6912-6917, 1988

114. Hoffmann D, Rivenson A, Abbi R and Wynder EL: A study of tobacco carcinogenesis: effect of the fat content of the diet on the carcinogenic activity of 4-(methylnitrosamino)-1-(3-pyridyl)-1butanone in F344 rats. Cancer Res 53: 2758-2761, 1993.

115. Wang M, Abbruzzese JL, Friess H, et al: DNA adducts in human pancreatic tissues and their potential role in carcinogenesis. Cancer Res 58: 38-41, 1998.

116. Hoffmann D, Rivenson A, Chung FL and Hecht SS: Nicotinederived N-nitrosamines (TSNA) and their relevance in tobacco carcinogenesis. Crit Rev Toxicol 21: 305-311, 1991.

117. Hecht SS and Hoffmann D: Tobacco-specific nitrosamines, an important group of carcinogens in tobacco and tobacco smoke. Carcinogenesis 9: 875-884, 1988 .

118. Hecht SS: DNA adduct formation from tobacco-specific N-nitrosamines. Mutat Res 424: 127-142, 1999.

119. Staretz ME and Hecht SS: Effects of phenethyl isothiocyanate on the tissue distribution of 4-(methylnitrosamino)-1-(3-pyridyl)-1butanone and metabolites in F344 rats. Cancer Res 55: 5580-5588, 1995.

120. Morse MA, Wang CX, Stoner GD, et al: Inhibition of 4-(methylnitrosamino)-1-(3-pyridyl)-1-butanone-induced DNA adduct formation and tumorigenicity in the lung of F344 rats by dietary phenethyl isothiocyanate. Cancer Res 49: 549-553, 1989.

121. Van BJ, Feron VJ, Leeman WR, Wilmer JW, Vermeulen E, den Engelse L and Scherer E: Immunocytochemical identification of DNA adducts, O6-methylguanine and 7-methylguanine, in respiratory and other tissues of rat, mouse and Syrian hamster exposed to 4-(methylnitrosamino)-1-(3-pyridyl)-1-butanone. Carcinogenesis 15: 2023-2029, 1994.

122. Baskaran K, Laconi S and Reddy MK: Transformation of hamster pancreatic duct cells by 4-(methylnitrosamino)-1-(3-pyridyl)-1butanone (NNK), in vitro. Carcinogenesis 15: 2461-2466, 1994.

123. Kolar C and Lawson T: Mutagenicity of carcinogenic nitrosamines when activated by hamster and human pancreatic duct epithelial cells. Cancer Lett 117: 149-154, 1997.

124. Correa E, Joshi PA, Castonguay A and Schuller HM: The tobacco-specific nitrosamine 4-(methylnitrosamino)-1-(3-pyridyl)1-butanone is an active transplacental carcinogen in Syrian golden hamsters. Cancer Res 50: 3435-3438, 1990.

125. Schuller HM, Jorquera R, Lu X, Riechert A and Castonguay A: Transplacental carcinogenicity of low doses of 4-(methylnitrosamino)-1-(3-pyridyl)-1-butanone administered subcutaneously or intratracheally to hamsters. J Cancer Res Clin Oncol 120: 200-203, 1994.

126. Schuller HM, Jorquera R, Reichert A and Castonguay A: Transplacental induction of pancreas tumors in hamsters by ethanol and the tobacco-specific nitrosamine 4-(methylnitrosamino)-1(3-pyridyl)-1-butanone. Cancer Res 53: 2498-2501, 1993.

127. Zhang L, Weddle DL, Thomas PE, Zheng B, Castonguay A, Schuller HM and Miller MS: Low levels of expression of cytochromes P-450 in normal and cancerous fetal pancreatic tissues of hamsters treated with NNK and/or ethanol. Toxicol Sci 56 $313-323,2000$.
128. Schulze J, Richter E, Binder U and Zwickenpflug W: Biliary excretion of 4-(methylnitrosamino)-1-(3-pyridyl)-1-butanone in the rat. Carcinogenesis 13: 1961-1965, 1992.

129. Peterson LA, Ng DK, Stearns RA and Hecht SS: Formation of $\operatorname{NADP}(\mathrm{H})$ analogs of tobacco-specific nitrosamines in rat liver and pancreatic microsomes. Chem Res Toxicol 7: 599-608, 1994.

130. Zhang S, Wang M, Villalta PW,Lindgren BR, Upadhyaya P,Lao Y and Hecht SS: Analysis of pyridyloxobutyl and pyridylhydroxybutyl DNA adducts in extrahepatic tissues of F344 rats treated chronically with 4-(methylnitrosamino)-1-(3-pyridyl)-1-butanone and enantiomers of 4-(methylnitrosamino)-1-(3-pyridyl)-1butanol. Chem Res Toxicol 22: 926-936, 2009.

131. Schuller HM, Kabalka G, Smith G, Mereddy A, Akula M and Cekanova M: Detection of overexpressed COX-2 in precancerous lesions of hamster pancreas and lungs by molecular imaging: implications for early diagnosis and prevention. Chem Med Chem 1: 603-610, 2006

132. Schuller HM, Zhang L, Weddle DL, Castonguay A, Walker K and Miller MS: The cyclooxygenase inhibitor ibuprofen and the FLAP inhibitor MK886 inhibit pancreatic carcinogenesis induced in hamsters by transplacental exposure to ethanol and the tobacco carcinogen NNK. J Cancer Res Clin Oncol 128: 525-532, 2002

133. Schuller HM, Tithof PK, Williams M and Plummer H, III The tobacco-specific carcinogen 4-(methylnitrosamino)-1-(3pyridyl)-1-butanone is a beta-adrenergic agonist and stimulates DNA synthesis in lung adenocarcinoma via beta-adrenergic receptor-mediated release of arachidonic acid. Cancer Res 59: 4510-4515, 1999.

134. Wu WK, Wong HP, Luo SW, et al: 4-(Methylnitrosamino)-1-(3pyridyl)-1-butanone from cigarette smoke stimulates colon cancer growth via beta-adrenoceptors. Cancer Res 65: 5272-5277, 2005.

135. Ye YN, Liu ES, Shin VY, Wu WK and Cho CH: The modulating role of nuclear factor-kappaB in the action of alpha7-nicotinic acetylcholine receptor and cross-talk between 5-lipoxygenase and cyclooxygenase- 2 in colon cancer growth induced by 4 -(N-methylN-nitrosamino)-1-(3-pyridyl)-1-butanone. J Pharmacol Exp Ther 311: 123-130, 2004.

136. Askari MD, Tsao MS and Schuller HM: The tobacco-specific carcinogen, 4-(methylnitrosamino)-1-(3-pyridyl)-1-butanone stimulates proliferation of immortalized human pancreatic duct epithelia through beta-adrenergic transactivation of EGF receptors. J Cancer Res Clin Oncol 131: 639-648, 2005

137. Laag E, Majidi M, Cekanova M, Masi T, Takahashi T and Schuller HM: NNK activates ERK1/2 and CREB/ATF-1 via beta-1-AR and EGFR signaling in human lung adenocarcinoma and small airway epithelial cells. Int J Cancer 119: 1547-1552, 2006.

138. Schuller HM and Orloff M: Tobacco-specific carcinogenic nitrosamines. Ligands for nicotinic acetylcholine receptors in human lung cancer cells. Biochem Pharmacol 55: 1377-1384, 1998.

139. Jull BA, Plummer HK, III and Schuller HM: Nicotinic receptormediated activation by the tobacco-specific nitrosamine NNK of a Raf-1/MAP kinase pathway, resulting in phosphorylation of c-myc in human small cell lung carcinoma cells and pulmonary neuroendocrine cells. J Cancer Res Clin Oncol 127: 707-717, 2001.

140. Minna JD: Nicotine exposure and bronchial epithelial cell nicotinic acetylcholine receptor expression in the pathogenesis of lung cancer. J Clin Invest 111: 31-33, 2003.

141. Gahring LC and Rogers SW: Neuronal nicotinic acetylcholine receptor expression and function on nonneuronal cells. AAPS J 7: E885-E894, 2005.

142. Maneckjee R and Minna JD: Opioids induce while nicotine suppresses apoptosis in human lung cancer cells. Cell Growth Differ 5: 1033-1040, 1994

143. Arredondo J, Chernyavsky AI and Grando SA: The nicotinic receptor antagonists abolish pathobiologic effects of tobaccoderived nitrosamines on BEP2D cells. J Cancer Res Clin Oncol 132: 653-663, 2006

144. Arredondo J, Chernyavsky AI and Grando SA: Nicotinic receptors mediate tumorigenic action of tobacco-derived nitrosamines on immortalized oral epithelial cells. Cancer Biol Ther 5: 511-517, 2006.

145. Arredondo J, Chernyavsky AI, Jolkovsky DL, Pinkerton KE and Grando SA: Receptor-mediated tobacco toxicity: alterations of the NF-kappaB expression and activity downstream of alpha7 nicotinic receptor in oral keratinocytes. Life Sci 80: 2191-2194, 2007. 
146. Xu L and Deng X: Tobacco-specific nitrosamine 4-(methylnitrosamino)-1-(3-pyridyl)-1-butanone induces phosphorylation of mu- and m-calpain in association with increased secretion, cell migration, and invasion. J Biol Chem 279: 53683-53690, 2004.

147. Jin Z, Gao F, Flagg T and Deng X: Tobacco-specific nitrosamine 4-(methylnitrosamino)-1-(3-pyridyl)-1-butanone promotes functional cooperation of $\mathrm{Bcl} 2$ and $\mathrm{c}-\mathrm{Myc}$ through phosphorylation in regulating cell survival and proliferation. J Biol Chem 279: 40209-40219, 2004.

148. Pour P, Althoff J, Kruger FW and Mohr U: Improvement of pancreatic cancer model by modified treatment with N-nitroso-bis (2-oxopropyl) amine. Cancer Lett 2: 233-237, 1977.

149. Grippo PJ and Sandgren EP: Modeling pancreatic cancer in animals to address specific hypotheses. Methods Mol Med 103: 217-243, 2005

150. Furukawa F, Nishikawa A, Yoshimura H, Mitsui M, Imazawa $T$, Ikezaki S and Takahashi M: Effects of 4-(methylnitrosamino)1-(3-pyridyl)-1-butanone (NNK) on N-nitrosobis(2-oxopropyl) amine (BOP)-initiated carcinogenesis in hamsters. Cancer Lett 86: 75-82, 1994.

151. Furukawa F, Nishikawa A, Enami T, et al: Promotional effects of 4-(methylnitrosamino)-1-(3-pyridyl)-1-butanol (NNAL) on $\mathrm{N}$-nitrosobis(2-oxopropyl)amine (BOP)-initiated carcinogenesis in hamsters. Food Chem Toxicol 35: 387-392, 1997.

152. Kimura K, Satoh K, Kanno A, et al: Activation of Notch signaling in tumorigenesis of experimental pancreatic cancer induced by dimethylbenzanthracene in mice. Cancer Sci 98: 155-162, 2007.

153. Osvaldt AB, Wendt LR, Bersch VP, Backes AN, de Cassia AS, Edelweiss MI and Rohde L: Pancreatic intraepithelial neoplasia and ductal adenocarcinoma induced by DMBA in mice. Surgery 140: 803-809, 2006.

154. Rivera JA, Graeme-Cook F, Werner J, et al: A rat model of pancreatic ductal adenocarcinoma: targeting chemical carcinogens. Surgery 122: 82-90, 1997.

155. Jimenez RE, Z'graggen K, Hartwig W, Graeme-Cook F, Warshaw AL and Fernandez-del CC: Immunohistochemical characterization of pancreatic tumors induced by dimethylbenzanthracene in rats. Am J Pathol 154: 1223-1229, 1999.

156. Sperti C, Militello C, Rovati L, et al: Effect of cholecystokinin analogue caerulein and cholecystokinin antagonist lorglumide on pancreatic carcinogenesis in the rat. J Surg Oncol 57: 11-16, 1994.

157. Matsuno S, Ejiri T, Kobari M, Yamauchi $\mathrm{H}$ and Sato T: Effects of immunosuppressive acidic protein on DMBA-induced pancreatic cancer in rats. Tohoku J Exp Med 144: 189-202, 1984.

158. Black O Jr, Murrill E and Fanska C: Metabolism of a carcinogen (7,12-dimethylbenzanthracene) in the pancreas of the LongEvans rat. Res Commun Chem Pathol Pharmacol 33: 103-118, 1981.

159. Bockman DE, Black O Jr, Mills LR and Webster PD: Origin of tubular complexes developing during induction of pancreatic adenocarcinoma by 7,12-dimethylbenz(a)anthracene. Am J Pathol 90: 645-658, 1978.

160. Rao MS and Reddy JK: Histogenesis of pseudo-ductular changes induced in the pancreas of guinea pigs treated with N-methyl-Nnitrosourea. Carcinogenesis 1: 1027-1037, 1980.

161. Carriere C, Seeley ES, Goetze T, Longnecker DS and Korc M: The Nestin progenitor lineage is the compartment of origin for pancreatic intraepithelial neoplasia. Proc Natl Acad Sci USA 104: 4437-4442, 2007.

162. Zhu L, Shi G, Schmidt CM, Hruban RH and Konieczny SF: Acinar cells contribute to the molecular heterogeneity of pancreatic intraepithelial neoplasia. Am J Pathol 171: 263-273, 2007.
163. Guerra C, Schuhmacher AJ, Canamero M, et al: Chronic pancreatitis is essential for induction of pancreatic ductal adenocarcinoma by K-Ras oncogenes in adult mice. Cancer Cell 11: 291-302, 2007.

164. Strobel O, Dor Y, Stirman A, Trainor A, Fernandez-del CC, Warshaw AL and Thayer SP: Beta cell transdifferentiation does not contribute to preneoplastic/metaplastic ductal lesions of the pancreas by genetic lineage tracing in vivo. Proc Natl Acad Sci USA 104: 4419-4424, 2007.

165. Strobel O, Dor Y, Alsina J, et al: In vivo lineage tracing defines the role of acinar-to-ductal transdifferentiation in inflammatory ductal metaplasia. Gastroenterology 133: 1999-2009, 2007.

166. Habbe N, Shi G, Meguid RA, et al: Spontaneous induction of murine pancreatic intraepithelial neoplasia (mPanIN) by acinar cell targeting of oncogenic Kras in adult mice. Proc Natl Acad Sci USA 105: 18913-18918, 2008.

167. Gingell R, Wallcave L, Nagel D, Kupper R and Pour P: Metabolism of the pancreatic carcinogens N-nitroso-bis(2-oxopropyl)amine and N-nitroso-bis(2-hydroxypropyl)amine in the Syrian hamster. J Natl Cancer Inst 57: 1175-1178, 1976.

168. Lijinsky W, Saavedra JE and Kovatch RM: Carcinogenesis and nucleic acid alkylation by some oxygenated nitrosamines in rats and hamsters. Chem Biol Interact 66: 37-47, 1988.

169. Satake K, Umeyama K, Kamino K, Uchima K and Yamashita K: Pancreatic cancer developing in Sprague-Dawley rats after local application of 7,12-dimethyl benzanthracene (DMBA). Osaka City Med J 21: 119-126, 1975.

170. Satake K,MukaiR,Kato Y,Shim K and Umeyama K: Experimental pancreatic carcinoma as a model of human pancreatic carcinoma. Clin Oncol 10: 27-34, 1984.

171. Lijinsky W, Reuber MD and Reznik-Schuller HM: Contrasting carcinogenic effects of nitroso-2,6-dimethylmorpholine given by gavage to F344 rats and Syrian golden hamsters. Cancer Lett 16: 281-286, 1982

172. Kokkinakis DM and Scarpelli DG: Carcinogenicity of $\mathrm{N}$-nitroso(2-hydroxypropyl)(2-oxopropyl)amine, N-nitrosobis(2hydroxypropyl)amine and cis-N-nitroso-2,6-dimethylmorpholine administered continuously in the Syrian hamster, and the effect of dietary protein on N-nitroso(2-hydroxypropyl)(2-oxopropyl) amine carcinogenesis. Carcinogenesis 10: 699-704, 1989.

173. Pour P, Gingell R, Langenbach R, Nagel D, Grandjean C, Lawson T and Salmasi S: Carcinogenicity of N-nitrosomethyl(2oxopropyl)amine in Syrian hamsters. Cancer Res 40: 3585-3590, 1980.

174. Cullingworth J, Hooper ML, Harrison DJ, Mason JO, Sirard C, Patek CE and Clarke AR: Carcinogen-induced pancreatic lesions in the mouse: effect of Smad4 and Apc genotypes. Oncogene 21: 4696-4701, 2002.

175. Reddy JK and Rao MS: Pancreatic adenocarcinoma in inbred guinea pigs induced by n-methyl-N-nitrosourea. Cancer Res 35 : 2269-2277, 1975.

176. Shirai T, Kato K, Futakuchi M, Takahashi S, Suzuki S, Imaida K and Asamoto M: Organ differences in the enhancing potential of 2-amino-1-methyl-6-phenylimidazo[4,5-b]pyridine on carcinogenicity in the prostate, colon and pancreas. Mutat Res 506-507: 129-136, 2002

177. Zhu J, Rashid A, Cleary K, et al: Detection of 2-amino-1-methyl6-phenylimidazo [4,5-b]-pyridine (PhIP)-DNA adducts in human pancreatic tissues. Biomarkers 11: 319-328, 2006.

178. Elkort RJ, Handler AH and Williams DL: Early neoplasia of rabbit pancreatic ductal cells induced dimethylhydrazine. Cancer Res 35: 2292-2294, 1975. 